4. Education and Training Committee of the European and African Division of the International Society of Hematology. Model graduate training programme for an accredited haematologist. Newsletter of the European and African Division of the International Society of Hematology 1991; 1: 29-30.

5. Shinton NK. Organisation of graduate training in haematology. Newsletter of the European and African Division of the International Society of Hematology 1991; 1: 27-28.

6. Joint Royal Colleges of Physicians' Training Board. Specialty training curriculum for haematology. http://www.jrcptb.org.uk/specialties/ST3SpR/Pages/Haematology.aspx (accessed 25 July 2010).

7. The Colleges of Medicine of South Africa. Regulations for admission to the examination for the post-specialisation sub-speciality certificate in infectious diseases, Cert ID (SA). http://www.collegemedsa.ac.za/force_download. asp?Path=Documents $\backslash$ doc_1077.pdf\&Name=Cert\%20ID(SA)\%20Path\%20 Regulations (accessed 25 July 2010)

8. Flexner A. Medical Education in the United States and Canada. A Report to the Carnegie Foundation for the Advancement of Teaching Bulletin Number Four. New York: Carnegie Foundation for the Advancement of Teaching, 1910.

\section{Vuvuzelas: Ex Africa semper aliquid novis - again?}

To the Editor: The vuvuzela, or lepata (Tswana), or 'stadium horn', has recently become an object of intense interest because of its prominence during the FIFA World Cup in South Africa. Its history has been well documented. ${ }^{1}$ We all now know what a vuvuzela is. Its monotonous sound, if produced simultaneously by, say, 40000 soccer enthusiasts, can fill an entire stadium for hours on end, to the intense irritation of players, coaches, non-participating spectators, TV audiences, and many more (for miles around the stadium).

The impact of the vuvuzela on the human ear has recently been studied, and the recreational risk that vuvuzelas pose to spectators in a stadium is significant. ${ }^{2}$ It may also disseminate droplet-spread infections and be used as a weapon by soccer hooligans; among other things, it has been described as 'an instrument from hell'.

Despite these negatives, Mr Sepp Blatter felt that 'We should not try to Europeanize an African World Cup ... that is what African and South African football is all about - noise, excitement, dancing, shouting and enjoyment.' Therefore, as a voice of moderation in favour of the accursed instrument, FIFA permitted the vuvuzela to be used in the 2010 WC stadia. And the 2010 FIFA WC went off well. A minimum of crime was reported, and no significant soccer hooliganism. There was even a respectful hush before each national anthem. South Africa scored very high points in the international media for the way in which the WC was presented.

I am of the considered opinion that the vuvuzela must have played a role in pacifying the crowds - possibly by keeping its users occupied. It kept their hands, mouths, lungs and minds busy while at the same time producing noise. There was apparent competition between users to see who could make the most noise. People of all ages, sexes and colours blew the vuvuzela. It even found its way into some royal circles. It must have had some energy-draining effect, energy that could otherwise have swelled into soccer hooliganism or even crime. It seemed to have some binding effect on fans from various countries. If indeed some potentially 'bad' energy, however little, was dissipated in this way, and if indeed it possibly had some unifying, positive, syncretic effect between peoples of different ethnic groups and nationalities, then I would be quite happy to continue living with the vuvuzela, even if it means some degree of hearing loss and living with some noise pollution. After all, Africa is a loud, bright, noisy and sometimes infernal continent.

In South Africa, we have just produced a new antiviral vaginal gel, which seems to be effective; we have produced yet another golf champion; and we have put the vuvuzela in the limelight. Possibly the vuvuzela is not all bad news. As the old Romans said: Ex Africa semper aliquid novis. (There is always something new out of Africa.)

\section{J du T Zaaijman}

Middelburg, Eastern Cape

zaaij@adsactive.com

1. Wikipedia. Vuvuzela. http://en.wikipedia.org/wiki/vuvuzela 2010.

2. Swanepoel De Wet, Hall JW. Football match spectator sound exposure and effect on hearing: A pretest-post-test study. S Afr Med J 2010; 100(4): 239-242.

\section{CRP and toxic granulation}

To the Editor: I read the article on CRP and toxic granulation with great interest. ${ }^{1}$ The authors concluded: 'The proposed system can be applied to patients with inflammatory or infectious conditions, where grading of toxic granulation of neutrophils can possibly be used as a surrogate marker to assess infection or inflammation and their response to treatment.' I agree that the new system can be useful in clinical practice. However, there are some points of concern. Firstly, the assessment of toxic granulation must be based on experienced clinical microscopy; ${ }^{2}$ this might not be available in rural hospitals. Secondly, there are many confounding factors that can affect the CRP level, and this aspect was not totally controlled in the article. ${ }^{3}$

\section{Viroj Wiwanitkit}

Wiwanitkit House

Bangkok

Thailand 10160

wviroj@yahoo.com

1. Van de Vyver A, Delport EF, Esterhuizen M, Pool R. The correlation between $\mathrm{C}$-reactive protein and toxic granulation of neutrophils in the peripheral blood. $\mathrm{S}$ Afr Med J 2010; 100: 442-444

2. Gulati GL, Hyun BH. Quality control in hematology. Clin Lab Med 1986; 6(4):675-688

3. Tomiyama R. Factors interfering with CRP assay (from the manufacturer's perspective). Rinsho Byori 2000; 48(8): 760-763.

Dr Van de Vyver replies: Laboratory confirmation of the presence of inflammation can be problematic in certain settings. This is a particular issue in settings where anti-inflammatory drugs - especially corticosteroids - are administered. In this setting, a combination of assays is usually employed to provide a cumulative impression of the presence or absence of infection or inflammation. C-reactive protein (CRP) is a widely utilised assay in the evaluation of inflammation. As with most immune assays, various factors can theoretically interfere with the final value reported. However, this seems to be a significant problem with highly sensitive assays (measuring levels below 10 $\mathrm{mg} / \mathrm{l})^{1}$ as opposed to assays measuring levels in excess of $10 \mathrm{mg} / \mathrm{l}^{2}$

We agree that assessment of toxic granulated neutrophils requires an experienced technologist, unfortunately not generally available in rural areas. The system is also potentially labour-intensive, with reproducibility highly dependent on the training of the examiners.

Toxic granulation can only serve as an additional tool to assess the presence of infection if there is diagnostic uncertainty. As a single parameter, it is of limited diagnostic value and can serve purely as a contribution to other infective markers.

1. Tomiyama R. Factors interfering with CRP assay (from the manufacturer's perspective). Rinsho Byori 2000; 48(8): 760-763.

2. Wilkins J, Gallimore JR, Moore EG, Pepys MB. Rapid automated high sensitivity enzyme immunoassays of C-reactive protein. Clin Chem 1998; 44: 1358-1361. 